\title{
The Development of Capacity In Organizational Learning Toward Digital Literation Process At The Fishing Ship Industries, In Pekalongan City
}

\author{
Hari Susanta Nugraha ${ }^{1}$, Saryadi $^{2}$, Widayanto ${ }^{3}$ \\ Departmen of Business Administration ${ }^{1}$, Department of Business Administration ${ }^{2}$, \\ Department of Marketing Management ${ }^{3}$ \\ \{harisusanta.nugraha@gmail.com\}
}

\begin{abstract}
A significant decline in business communication skills occurred in the fishing ship industries in Pekalongan City, due to the corona pandemic. In the beginning of March 2020 , the market absorption of the fishing ship industries began to decrease by $25 \%$ and continued to decline until the end of 2020. However, the fishing ship industries in Pekalongan city still finding the difficulties for entering the domestic market due to social restriction. This condition encourages the fishing ship industries to conduct business communications using digital devices. The research aims to recognize the implementation of business engagement by using digital devices. The qualitative methods used to identify problems in learning digital devices. The in-depth interviews were used to explore each identified problem. The research result shows that, the process of acquisition of digital devices in learning organization remain very low. There is an inability of digital literacy based on digital devices in business actors as measured by increasing the quantity of market networks. That is why, the market absorption has decreased significantly. The contribution of research is that the use of digital devices encouraged the capability to improve organizational capabilities in customer engagement.
\end{abstract}

Keywords: business communication; digital devices; organizational capability

\section{Introduction}

Organizational learning described the process through which knowledge is accumulated. The organizational learning process consists of knowledge acquisition, information distribution, information interpretation, and organizational memory[1]. However, The Fishing Boat Center in Pekalongan City is located in the North Pekalongan District. Data for 2019 The Fishing boat Center in Pekalongan City recorded some of 28 business units and showed significant growth in the number in 2020 to 32 business units. The scope of marketing areas has reached a over the nation.

In 2020 some buyers who explored the Fishing Boat Center in Pekalongan City and got the opportunity to be marketed overseas but have not been able to fully answer the challenges of global quality. The inability to compete in the global business arena becomes a material for introspection for craftsmen to work even harder by increasing the competitiveness of the business market. The need for the implementation of digital devices is caused by the need for factors that drive the acceleration of the learning process and the process of knowledge transfer in the central area. Problems related to digital literacy faced by fishing boat craftsmen in Pekalongan City based on observations can be seen in table 1 . 
Digital literacy is an understanding of digital devices used in everyday life, to solve problems related to ethics, morals, and business issues that are streamed through the network [2]. Understanding of performance and function, as well as containing digital devices plays an important role in building a knowledgeable society that has the skills to surf the media, communicate effectively, solve problems, and carry out social cooperation [3].

In fact, in the last 2 decades, reforms in Indonesia have encouraged the application of digital device technology in which digital literacy has become increasingly important. The importance of digital literacy is related to a person's ability to access and understand the contents of digital devices to help make decisions about the natural environment and changes resulting from human activities.

Table 1. Identification of Business Problems Related to Business Process Digitization Needed at the Fishing Boat Center of Pekalongan City

\begin{tabular}{|c|c|c|c|}
\hline Numb. & Locus & Indicators & The fact observed \\
\hline 1. & $\begin{array}{l}\text { Production } \\
\text { areas }\end{array}$ & - $\quad$ characteristics & $\begin{array}{l}\text { The absence of quality standards for production in } \\
\text { terms of pre-production, process, and post- } \\
\text { production. Many products that are ready to be } \\
\text { marketed still look untidy and inadequate } \\
\text { handling is done when they are handed over to the } \\
\text { buyer. } \\
\text { The ship's product does not have a special } \\
\text { identifying standard and there is no product name. } \\
\text { There are no maintenance manuals and } \\
\text { instructions embedded in the product. } \\
\text { The types of variations that can be created by } \\
\text { craftsmen are still limited; each crafter has } 2-3 \\
\text { variations of patterns that are mastered from } \\
\text { generation to generation. }\end{array}$ \\
\hline 2. & Price & $\begin{array}{ll}\text { - } & \text { Price's } \\
& \text { structure }\end{array}$ & $\begin{array}{l}\text { There is no definite calculation in the pricing } \\
\text { policy to encourage sales. Craftsmen do not have } \\
\text { a preference for the components of the calculation } \\
\text { of costs that determine the price level. } \\
\text { The price of the product is determined by external } \\
\text { forces (woods suppliers, workers, collectors or } \\
\text { buyers of goods). }\end{array}$ \\
\hline 3. & $\begin{array}{l}\text { Sales } \\
\text { distributions }\end{array}$ & $\begin{array}{ll}\text { - } & \begin{array}{l}\text { Scope of } \\
\text { market }\end{array} \\
\text { - } & \begin{array}{l}\text { Sales } \\
\text { relationship }\end{array}\end{array}$ & $\begin{array}{l}\text { Craftsmen ship products directly to buyers who } \\
\text { become regular customers for years. The } \\
\text { development of the number of agents/buyers is } \\
\text { relatively consistent from year to year. } \\
\text { The area and scope of the market have not } \\
\text { experienced significant development from year to } \\
\text { year. } \\
\text { Many ship buyers are in eastern Indonesia. In } \\
\text { terms of negotiating designs, prices, } \\
\text { specifications, and shipping administration, it } \\
\text { costs a lot and has an impact on high prices. }\end{array}$ \\
\hline
\end{tabular}

Source: Field observations at the Center of Fishing Boat Industries in Pekalongan city, 2020 
This research is analyzed from the perspective of the fishing boat industry's ability in terms of digital literacy. Digital literacy is an effort to educate the public in utilizing technology and communication by using digital technology and communication tools or networks to find, evaluate, use, manage, and create information wisely and creatively. The ability to read devices has an important contribution in building organizational learning[4].

However, the problem does not only arise in the cost aspect, but the main problem is how digital devices are able to make a significant contribution to business operations. Digital literacy ability is the ability to understand digital hardware and software used in everyday life, through processes. Verify, confirm, and validate the facts generated by digital devices. Digital literacy skills are implemented in the accuracy of business decision making.

\section{Research Problems}

The organizational learning capability in the firm inside the center of fishing boat industries are still very low. The fact showed that, the design of fishing boats is still very traditional based on habit and memories of the builders. The process of building boat carried out traditionally. That is why the boat had been built for 8-12 months. In addition, the boat is very costly. The secondary problems risen such as, uncertainty about the quality, the high rate of failure in building a ship, and no definite contract system.

The buyers of fishing boats are often located far away, as far as Papua, Ambon, and Nusa Tenggara; so that it requires high costs if direct contact to prepare designs, budget plans, and work contract approvals, on the other hand the design of fishing boats needs detailed discussion and requires the involvement of prospective owners in building it, not every time the prospective owner can come if needed.

\section{Organizational Learning in Practice}

In today's competitive communication technology-based business conditions, companies face dynamics of stakeholders working at an extraordinary pace, where maintaining agreements with stakeholders is crucial for business sustainability. To win in the company must be able to manage relationships with consumers that are difficult for other businesses to imitate. In the knowledge-based views of the firms, companies leverage stakeholder relationships for excellence and foster long-term competitive advantage [5].

Organizational intangible assets, such as organizational learning orientation [6] and market orientation, are very difficult to imitate by competitors. Researchers have noted significant progress in recent decades interpreting the effects of organizational learning orientation. This research builds a framework that business units need to pay attention to in managing relationships with stakeholders using digital devices.

The basis of organizational learning in this research is that the process by which the firm adapts its actions to the desired demands of its customer [2]. To operationalize organizational learning in the business unit, it is carried out such as introducing business networks and participating in fishermen's association activities. This method can be applied to managers and business unit leaders. Fishing boat industries carrying out organizational learning by demonstrating its capabilities on an ongoing basis [3].

The model for Organizational Learning in the ship industry in Pekalongan City uses the introduction of knowledge acquisition, knowledge dissemination, action interpretation, and 
knowledge storage models. In the initial stage, knowledge acquisition is carried out by using business unit leaders and several key persons as knowledge centers[4]. Leaders get information from stakeholders and distribute it to key person, namely the head of employees and the head of production, on a limited basis by using face-to-face.

Key knowledge shared directly includes ship's technical design, contract values, the contract periods, and ship licensing. Issues of production design, pricing, and delivery to consumers are discussed between the business unit leaders with the employees and the production department. Solutions in production problems discuss about; (1)The ship's quality level is determined by the wood material, the thickness of the wood, and the design of the ship's shape; (2)Characteristics include the type of boat, which is the highest type of purine and gillnet; and (3)Variations of ship products are determined by the type of engine and electronic devices. The decision of the discussion between the business unit leaders and the key persons could be the determines of the details of the work.

This approach is relevant to the model of direct learning [6], where groups within the organization are able to modify actions according to the assessment of the problem. The act of organizational learning in fishing boat companies synthesizes a knowledge acquisition model that greatly minimizes digital devices. In direct discussions, the use of digital devices is not much use. Knowledge acquisition model is done by direct learning interface.

The next action is carried out by the employee and the raw material section. The two key people use a digital device in the form of a cellular phone to make contact with each unit. In the act of disseminating knowledge, the employee division will determine the qualifications and number of workers, the number of wages, and the workload. The raw materials department will contact the wood and other material supply unit, determine the required quantity and determine payment. Model the relationship between workers and raw materials with each unit fully using digital tools. They build trust in digital communication because of the close relationship.

There are some issues from the sales point of views, however the fishing ship industries often uses flexible contracts, not even a written agreement. The use of gradual payments is often used in built the ships. by using a communication device, the agreement can be recorded and documented.

\section{Conclusion}

Digital devices use to empower the process of ship building. Adaptive learning namely changes that have been made in reaction to changes in environmental conditions and proactive learning, namely organizational changes that have been made on a more difficult basis to change. This is simple learning that goes beyond reacting to a changing environment.

\section{References}

[1] Bontis, N, Wiliam Chua Chong Keow dan Stanley Richardson. 2000. "Intellectual Capital and Business Performance in Malaysian Industries.” Journal of Intellectual Capital. Vol 1, No. 1, 85-100.

[2] Bontis, Nick \& Choo, C. W. (Eds.), 2002. The strategic management of intellectual capital and organizational knowledge. New York, NY: Oxford University Press

[3] Boisot.2002. The Creating and Sharing of Knowledge. The Strategic Management of Intellectual Capital and Organizational Learning. Oxfrod University Press.

[4] Clarkson, Michael, Mathiass Fink and Sascha Kraus, (2007), Industrial cluster as a factor for innovative drive- in region of transformation and structural change: A comparative analysis of East Germany and Poland. Journal for East Management Studies, 12(4),p.340-361

[5] Holsapple \& Joshi, (2000), An investigation of factors thta influence the management knowledge in the organizations. Journal of Strategic Management. 9(2/3),pp. 35-61. 
[6] Huang \& Liu. (2005). Exploration for the realtionship between innovation, IT and poerformance. Journal of Intellectual Capital. Bradford. 6(2). Pp.237

[7] Koencoro, Mudrajad, (2007). Social Capital for Empowering the SME's Cluster at Kasongan, Region of Bantul. Journal of Small and Business Management. 44(2).

[8] Malhotra N. K., Peterson, M. and Kleiser, S. B., (1999), "Marketing Research :A State-of-the-art Review and Directions for the Twenty-first Century",Journal of the Academy of Marketing Science, Vol. 27, 2, pp. 160-183

[9] Mei \& Nie. (2007). A strategic management framework for leveraging knowledge assets. International Journal of Innovation and Learning, 1(2), 115-142.

[10] Holsapple \& Joshi, (2000), An investigation of factors that influence the management knowledge in the organizations. Journal of Strategic Management. 9(2/3),pp. 35-61.

[11] Liao. (2005). Roles of Social Capital Venture Creation: Key dimension and research implication. Journal of Small Business and Management. Milwaukee. 43(4),p.359

[12] Mouritsen. (2004). Measuring and intervening: how do we theorise IC management. Journal of Intellectual Capital. Braford. 5(2),pp.257-267

[13] Mouritsen. et al, (2005). Dealing with the knowledge economy: IC versus Balanced Scorecard. Journal of Intellectual Capital. Braford. 6(1),pp.8-27

[14] Namasivayan \& Denizci. (2006). Human Capital in Service Organization: identifiying value drivers. Journal of Intellectual Capital. Bradford. 7(3).pp.381-393

[15] Garvin, David. (2000). Learning in Action; A Guide to putting the learning organization to work. Harvard Business Review. USA

[16] Guthrie, J. 2001. “The Management, Measurement and The Reporting Intellectual Capital.” Journal of Intellectual Capital. Vol 2, No. 1, 27-41.

[17] Keogh, et. al. (2005). The indentification and application of knowledge capital within the small firms. Journal of Intellectual Capital. Bradford. 12(1)pp.76-91

[18] Khan \& Ghani, (2004). Cluster and entrepreneurship; Implications for Innovations in a developing economy. Journal of Development Entrepreneurship. Bradford Dec. 9(3).

[19] Tambunan, Tulus. 2009. Enterpreneurship Development : SMES in Indonesia. Journal of Development Entrepreneurship Vol. 12, No. 1, pp. 95-118. World Scientific Publishing Company. 